\title{
Portugueses e experiências políticas: A luta e o pão. São Paulo 1870-1945
}

Maria Izilda Santos de MATOS ${ }^{\bullet}$

\begin{abstract}
Resumo: Este artigo pretende ser uma contribuição para o estudo das experiências cotidianas de imigrantes na cidade de São Paulo, no período entre 1870 e 1945. A análise procurará recuperar a teia de relações cotidianas na sua dimensão da experiência no mundo dos negócios e do trabalho, recobrando as atividades de produção e comercialização do pão, observando a trama das conexões e tensões que se estabeleciam entre proprietários e trabalhadores nas padarias, na sua maioria de origem portuguesa. Privilegiando a documentação do DEOPS (Departamento Estadual de Ordem Política e Social ), particularmente os prontuários, a proposta recupera enfrentamentos, formas de resistência, luta e greves que atingiram o setor da panificação.
\end{abstract}

Palavras-chave: Portugueses; Imigrantes; Padeiros, São Paulo, Cotidiano.

A aceleração da urbanização da cidade de São Paulo e sua consolidação como centro capitalista, integrador regional, mercado distribuidor e receptor de produtos e serviços foram fatores vinculados à expansão da produção cafeeira, num quadro no qual interagiram a desintegração da Abolição, a grande imigração e o êxodo rural.

Nesse processo, pode-se considerar como marco de mudança a chegada à cidade dos trilhos da Santos-Jundiaí (1863), que conectou São Paulo com o porto exportador- Santos e a com a zona produtora no interior do Estado. Os trilhos não só transportavam rápida e eficientemente o café, como também

- Professora Titular do Departamento de História - PUC-SP - 05014-901

- São Paulo - SP - Brasil. E-mail: mismatos@pucsp.br

HISTÓRIA, São Paulo, 28 (1): 2009 
traziam de várias partes do mundo, particularmente da Europa, toda uma gama de produtos e influências, gerando e dinamizando um "vetor modernizador" sobre a urbe (ELIAS, 1994).

A política desencadeada pela cafeicultura paulista, estimulando e promovendo intensamente a imigração, em proporções bem superiores às possibilidades de emprego no campo, favoreceu o crescimento da população urbana. Em momentos de queda do preço do café, geadas ou pragas, a evasão dos colonos do campo era acentuada. De acordo com o censo do ano de 1872, quando a cidade já sentia as consequências do surto cafeeiro, a população de São Paulo era de 31.385 pessoas. No censo seguinte, o de 1890, elevou-se para 64.934 habitantes, já no início do século XX, em 1900, eram 239.820 habitantes, e em 1920, a população da cidade mais do que dobrou, atingindo a cifra de 579.033 pessoas. $^{1}$

O florescimento da capital tornou-a um pólo de atração para os imigrantes. Alguns vieram diretamente para a cidade e outros, após uma rápida passagem pela lavoura, migravam à procura de melhores perspectivas, novas oportunidades e na busca da realização de seus sonhos. Com a presença acentuada destes recém chegados, gerou-se uma verdadeira metamorfose. Novos territórios ${ }^{2}$ se constituíam e passaram a receber as marcas dos grupos que ali se instalaram: os italianos no Bexiga, os japoneses na Liberdade, os judeus no Bom Retiro, os síriolibaneses na Vinte e Cinco de Março, os portugueses em Santana e no Sumaré e distribuídos em toda a cidade, mais ocultos os redutos dos negros na Barra Funda e Casa Verde.

Os recém chegados ${ }^{3}$ procuravam arranjar ocupações nas atividades urbanas, no setor fabril, comercial e de serviços, nas obras públicas e particulares. Eles enfrentavam as dificuldades de um cotidiano com grande concentração de trabalhadores, excedendo largamente as necessidades do mercado e aviltando os salários. Foram criadas formas múltiplas de atividades temporárias e domiciliares, subemprego, emprego flutuante e ampliando uma população que garantia a sua sobrevivência na base das ocupações casuais, às custas de improvisação de 
expedientes variados, eventuais e incertos, desenvolvendo experiências cumulativas de improvisação (MATOS, 2002).

O aumento da população com a chegada contínua dos imigrantes gerou novos hábitos, gostos e práticas de alimentação, que se tornaram mais variadas com a diversificação dos produtos oferecidos. Com isso, ampliaram-se as oportunidades para as atividades comerciais de abastecimento.

Entre as diferentes categorias de vendedores ambulantes, que retiravam sua sobrevivência do comércio nas ruas, os imigrantes se encaixavam entre aqueles que ofereciam gêneros de abastecimento fundamentais à rotina doméstica, comercializados em pequenas quantidades que eram renovadas dia a dia. Utilizando-se de carrocinhas de madeiras, eles comercializavam verduras, frutas, flores, ovos, aves, carnes, peixes, leite e também pão.

Alguns recém chegados começaram como ambulantes, mas, com muito empenho, trabalho e poupança, conseguiram se estabelecer em pequenos negócios, outros, graças a seus tinos comerciais, ascenderam à posição de comerciante, partindo daí para a diversificação de seus interesses ${ }^{4}$.

Os imigrantes destacaram-se principalmente no comércio a retalho, estabeleceram-se em negócios de pequeno e médio porte, na maioria unidades familiares: alfaiatarias, lojas de roupas, tecidos, armarinhos e miudezas, ferragens, louças, vidros, nos setores de serviços e alimentício. Procurando trabalhar com um custo operacional mínimo eles aproveitaram o quarto da frente de suas próprias casas para constituírem pequenos armazéns de secos e molhados, açougues, adegas ${ }^{5}$, quitanda de frutas e legumes, vendas e botequins.

Entrecruzando o público e o privado, o negócio e o lar, a família trabalhava duramente no balcão de madrugada a madrugada. Os poucos auxiliares eram, em geral, também imigrantes, que se colocavam sob a tutela de conterrâneos. Estabeleceram negócios variados, como: quitandas, mercearias ${ }^{6}$, leiterias, açougues, bares, cafés, botequins, restaurantes, pastelarias, tabernas, também nos hotéis, pensões e casas de cômodos, com ou sem o fornecimento de refeições, e 
particularmente as padarias e confeitarias ${ }^{7}$. Alguns destes estabelecimentos eram mais simples, outros mais sofisticados, com mesinhas, lustres, cristais, espelhos, buscavam reproduzir um estilo europeu e ser aconchegantes e chiques, as referências nos anúncios da imprensa eram frequentes.

Nas confeitarias e docerias, serviam doces, cremes, chás, chocolates e sorvetes, algumas se tornaram pontos de encontro e se sofisticaram. Os restaurantes, que se fizeram notar desde a década de 1850, expandiram-se depois dos anos de 1870, particularmente no início do século XX, quando se passou a fazer com mais frequência as refeições fora (especialmente o almoço), devido às distancias entre o trabalho e a casa.

Nesse período, surgiram restaurantes de diferentes tipos, alguns ofereciam refeições mais simples, outros, mais sofisticadas. Através dos cardápios, divulgados nos anúncios de jornais, pode-se observar a presença de pratos regionais, nacionais e estrangeiros. A influência estrangeira foi crescente, particularmente, a dos menus franceses e do modelo de servir a "table ronde", com cardápio definido e preço fixo por pessoa. A presença dos imigrantes, com seus gostos, práticas e sabores, levou à diversificação do setor, com destaque inicial para os italianos, mas também se fizeram presentes as marcas dos portugueses, espanhóis e de outras nacionalidades (SILVA, 2007).

\section{Com a mão na massa: Fazer o Pão}

Em São Paulo, até a segunda metade do século XIX, as mulheres eram as principais responsáveis pela elaboração do pão, que era produzido majoritariamente com milho e mandioca. Elas se ocuparam das tarefas de preparar a farinha, peneirar, fazer a massa e assar os pães ${ }^{8}$. Algumas trabalhavam para outras mulheres, donas dos fornos e da matéria-prima e vendiam nas ruas e/ou entregavam nos domicílios ${ }^{9}$. 
A partir da segunda metade do século XIX, as transformações na cidade foram influenciadas pelos imigrante $\mathrm{s}^{10}$, que entre os novos gostos e práticas difundiram o uso do trigo (da farinha de trigo), particularmente para a elaboração dos pães. Estabeleceram-se padarias que viabilizavam uma produção maior, sistematizada e cotidiana adequada ao crescimento da demanda. Neste processo, a atividade feminina foi substituída pelo trabalho de homens, particularmente solteiros, de forma que as mulheres passaram a não mais atuar nos espaços de fazer o pão ${ }^{11}$.

Os responsáveis iniciais pela expansão da panificação na cidade foram os imigrantes italianos. As padarias, na maioria dos casos, eram empresas familiares, destacaram-se a Santa Tereza (1872), Ayrosa (1888), Popular (1890, da família Di Cunto). Elas produziam os chamados "pães caseiros" com fermentação natural, o que os tornava mais saborosos nos dias seguintes, sendo assim, a maioria dos clientes adquiriam o produto para 2 ou 3 dias, o que facilitava a organização dos horários e o descanso semanal.

O setor da panificação se difundiu com a ampliação da influência das chamadas padarias e confeitarias francesas e o do pão do tipo francês. A partir de 1860, nos jornais da capital paulista o número de anúncios de padarias e de procura de padeiros cresceu, permitindo avaliar como a panificação ganhara um incremento inusitado. Os anúncios ocupavam várias páginas, revelando as mudanças de hábitos, o desenvolvimento comercial da cidade e o aumento de um contingente de imigrantes que se envolveram na atividade de preparo e venda do pão. 


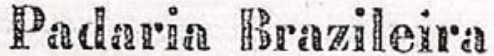

RUA dO ROZaRio N.・ 30

N'oste estobelecimonto novamento prepnrado com limpeza continua-so a fabricar pìis do todas as qualidotles, biscoutos, roscas, sequilhos, bnlaxas, bisconlos doces para servir ao chà, do diṭ̛?o. rontos qualidades. Venda-so ossucar refinado, arrobado, o as libras, suporior qualidado de manteigos, rellas do cohı, e composiçāo, vinhos, sorveja ingleza pretn e branca, conservas licores de diversas qualidados, refrescos de tamarindos, orxata, dita etn pó, grozeille, xaropo do vinagro, dito de limảo, dito do goma o outros, ludo par preços muito inferiores aos actuaes; o moitns outros goneros de molbados. Apromtāo-so re. ceitas dos mesmos para lóta corn promptidão, nas quacs so fiz differença nos preços conformu s poręão, tanto nos molhados, como nos objeclos do massas, o assucar. $\Lambda$ liança.so a boo qualidade tlos generos, os quaes nõo agradando ao compros dor acceita-so restituindo-so sou importo.

O estabolecinonto está as ordens para quem quizer olsservar so o trabal ho é, ou não faito com limpeza, poulendo ser visto a qualquer hora da

Correio paulistano, 25 de setembro de 1862

Os anúncios na imprensa permitem observar toda a variedade de pães que era oferecida, com destaque para o pão francês, mas também para a bisnaga, o pão de família, o de Paris, o pão-de-rala (feito com centeio e milho), o pão de leite (com ovos e açúcar), o meleças, o saloio ${ }^{12}$, o quartado (mistura de farinhas de trigo, centeio, cevada e milho) e outras qualidades. Somava-se um grande sortimento de roscas, tranças, biscoitos, sequilhos e bolachas. As padarias (misto de mercearias) também ofereciam café moído, leite puro, de todos os produtos "afiançase a boa qualidade e os preços cômodos".

Com a propagação do uso do fermento biológico tornou mais ágil a forma de preparar o pão, permitindo a produção de 
várias fornadas diárias, com pão quente a toda hora. Algumas padarias ofereciam pão quente desde as 5 horas até as 9 horas da manhã, de tarde entre as 3 e 5 horas e das 7 até as 9 horas, além de se proporem a aprontar "encomendas para fora com toda a brevidade", para festas, casamentos, batizados, etc.

Estas práticas foram difundidas particularmente nas padarias de propriedade dos portugueses, que também inovaram a organização do negócio com a incorporação de vários sócios que se revezavam em diferentes turnos, garantindo o funcionamento dos estabelecimentos 7 dias por semana e por quase 20 horas diárias. Neste setor, os portugueses se destacaram, eles integravam todas as etapas da produção do pão: donos de padarias, fornecedores de lenha e carvão para os fornos, trabalhavam como masseiros, forneiros, carvoeiros e entregadores.

Com o crescimento do setor, em 1915, os proprietários de padarias constituíram a União dos Proprietários de Padarias de São Paulo, reunindo portugueses, italianos e espanhóis. O Estatuto Social foi aprovado na primeira Assembléia Geral, ocorrida no dia 9 de Março, quando além de discutirem os assuntos pertinentes à estruturação da entidade, foram levantadas as questões que mais incomodavam os panificadores naquele momento (PERISSINI, 2005).

Nesta ocasião, foi proposta a constituição de um cadastro de fregueses (buscando selecionar os bons pagadores) e particularmente um cadastro de empregados. A organização do cadastro de empregados pretendia organizar informações quanto ao caráter, assiduidade e engajamento político, buscando direcionar os patrões na hora das contratações, identificando os "indesejáveis", inclusive levando à demissão, suspensão, multas e ridicularização.

O cadastro de empregados foi uma das primeiras disposições e buscava o registro de todos os demitidos das padarias, os proprietários comunicavam os nomes dos trabalhadores e os motivos de sua demissão, que eram divulgados pelas padarias, impedindo que ele encontrasse novo emprego. Os motivos mais citados eram falta de assiduidade e roubo, todavia a acusação de 
roubo poderia ser utilizada para encobrir demissões relacionadas às atividades políticas, apesar de se encontram nas listas alguns operários declarados como "agitadores", "insubordinados" e "subversivos".

Exemplar foi o caso do padeiro Eleutério do Nascimento, preso em setembro de 1934, sendo identificado pela polícia como um "perigoso ladrão" ${ }^{13}$. Mas o noticiário do jornal A Plebe esclarecia a situação, destacando as prisões arbitrárias de trabalhadores e sindicalistas. Neste caso, a prisão ocorreu justamente durante a greve dos padeiros de 1934, capitaneada pelo Sindicato dos Padeiros, sendo Eleutério um dos líderes do movimento:

Conhecido como é esse companheiro entre os trabalhadores de sua classe, de cujo Sindicato vem sendo, de há muito, honesto colaborador, essa notícia provocou a mais justa repulsa... não é ladrão, mas honesto trabalhador padeiro. ${ }^{14}$

A União dos Proprietários de Padarias também articulou os proprietários das padarias em torno das questões do abastecimento da farinha de trigo, especificamente, nos momentos de carestia do produto, como durante a Primeira Grande Guerra (1914-18). Outra questão que envolvia os proprietários foi a dos enfrentamentos com a Diretoria de Higiene Municipal, que, entre suas funções, buscava organizar e fiscalizar a higiene no local e durante o processo de produção do pão.

Neste momento, as ações do órgão público buscavam normatizar a localização das cocheiras junto às padarias. Cotidianamente, a distribuição do pão era feita por entregadores em carrinhos, a maioria de tração animal (cavalos e burros), desta forma, atendia-se a freguesia que morava mais longe, ou que por comodidade, gostava de ter o pão entregue em sua casa. Depois das entregas, os carrinhos e os animais eram guardados em cocheiras instaladas junto às padarias, gerando polêmica com os órgãos de higiene, que propunham que estas cocheiras 
fossem instaladas fora do perímetro urbano, afastadas das padarias.

Segundo os proprietários, esta medida dificultaria o serviço de entregas. Após vários protestos dos proprietários e de sua entidade, as cocheiras foram mantidas junto às padarias, mas com a condição de serem azulejadas e conservadas sob rigorosas normas de higiene e limpeza.

A União dos Proprietários de Padarias de São Paulo encerrou suas funções em 1917, voltando a se constituir em 1920, com acirramentos das tensões entre patrões e empregados. Em 1922, a Câmara Municipal de São Paulo buscou regulamentar dias e horários de funcionamento das padarias, de forma a garantir o descanso semanal dos empregados ${ }^{15}$.

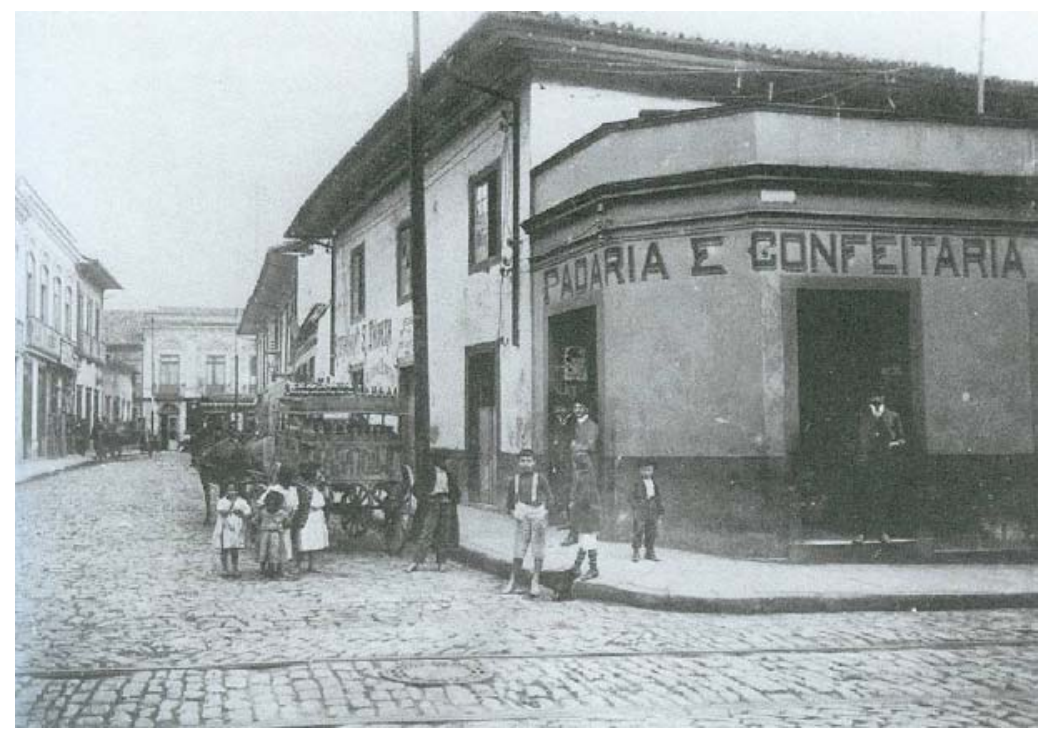

Frente à questão, a União dos Padeiros (órgão de representação dos empregados) iniciou a conversação com os 
patrões, destacando entre suas reivindicações a extinção do trabalho noturno com a concentração da fabricação do pão no período diurno. Os proprietários consideram a proposta impraticável, pois inviabilizaria as entregas matutinas que eram muito lucrativas para as padarias. Quanto ao descanso semanal, ficou estabelecida a segunda-feira, mas muitas padarias mantiveram sua produção neste dia.

As tensões cresciam principalmente frente à fiscalização da prefeitura, já que, em alguns casos, os fiscais eram mais rigorosos e em outros mais flexíveis. A associação patronal entrou com representação junto a Câmara Municipal de São Paulo buscando extinguir a lei.

Em 1925, novamente, a União dos Proprietários foi encerrada voltando a se constituir em 1928, como Associação dos Proprietários de Padarias de São Paulo, centrando suas ações nas questões com seus empregados e com a prefeitura, como: quanto ao descanso semanal, horários de trabalho, higiene nas cocheiras e no processo de fabricação do pão. Novos impasses constituíram-se com a Diretoria de Higiene, que buscava normatizar o acondicionamento do pão, que deveria ser embrulhado imediatamente após a saída do forno e não mais colocados e sacos, cestos ou tabuleiros ${ }^{16}$.

\section{O pão que o diabo amassou}

O fazer o pão exigia um conhecimento e habilidades profissionais, subentendendo um processo com diferentes etapas e hierarquias. Inicialmente o trigo era peneirado dentro de uma masseira de madeira, em separado fazia-se o fermento, em seguida misturavam-se os ingredientes que deveriam ser amassados "a muque" (utilizando-se a força física) ${ }^{17}$, só com experiência - através do toque - que se adquiria o conhecimento do ponto ideal da massa.

A massa já pronta descansava, dependendo da temperatura, esse processo era mais lento ou mais rápido. Posteriormente ela era cortada, pesada, sovada, para depois se 
modelarem os pães, que eram colocados em tábuas aprontandoos para serem levados ao forno, na hora de colocar no forno era que o corte do pão era dado.

O forno redondo de barro e tijolos não possuía termômetros, estando sob o controle do padeiro. Nas padarias maiores havia o forneiro, que devia preparar o forno (limpava, colocava a lenha, acendia o fogo) e, pela experiência, sentir a temperatura, sabendo o momento exato de colocar e retirar o pão do forno. Os pães eram colocados no forno com cuidado e habilidade, com a palheta, posicionava-os de um lado e retiravaos prontos de outro, estas ações exigiam atenção e prontidão para evitar que os pães ficassem crus ou torrados (FONTES, 2002).

A jornada de trabalho nesses estabelecimentos era longa, começava às 18 horas com o preparo da massa, estendia-se por toda a noite, já que às 4:30 horas o pão deveria estar pronto para a venda e para as entregas à freguesia. Já às 7 horas, começavam os preparativos para o pão da tarde, quando os instrumentos e o local eram limpos enquanto o pão estava sendo assado. O descanso era das 12 horas às 18 horas, contudo, este horário não era fixo, podendo ocorrer modificações.

Os padeiros também ajudavam no balcão e realizavam as entregas, mas em outros casos, a "freguesia era feita" pelo entregador, que iniciava o trabalho por volta das 4:30 horas e terminava por volta das 6:30 horas. Ele saía com um cesto grande e entregava em armazéns, bares e domicílios. Alguns entregadores comercializavam em carrocinhas (puxadas a burro ou cavalo, posteriormente motorizadas) que lhe permitia servir uma clientela mais distante.

A freguesia era constituída por uma parceria entre o freguês e o padeiro/entregador, que se empenhava em agradar e manter a clientela ${ }^{18}$. As relações estabelecidas entre eles subentendiam solidariedade e cobranças, várias eram as exigências quanto à pontualidade de horário na entrega, o tipo e qualidade do pão, as preferências (o pão mais torrado ou branquinho). Mesmo em momentos de dificuldades para a obtenção e controle sobre a farinha de trigo, que poderiam levar 
a perda de qualidade do pão, os padeiros se empenharam em servir a freguesia. O pagamento era realizado aos sábados, mas havia os que "acertavam" por quinzena e até por mês, logicamente, existiam os atrasos e as dívidas acumuladas.

O pão tinha que ser feito todos os dias, sendo imperdoável a falta do padeiro e não havendo descanso, sábados, domingos ou feriados. Para além da jornada extensa e noturna, sem repouso e da falta de folgas, deve-se destacar que todas as etapas do processo de preparação do pão eram árduas e pesadas, com dispêndio de força para a preparação da massa, além das altas temperaturas do local de trabalho. A esta situação, somava-se a insalubridade da função que causava mal aos pulmões e aos olhos, doenças cardíacas e pulmonares, como tuberculose, asma e pneumonia, além de reumatismo, queimaduras e varizes.

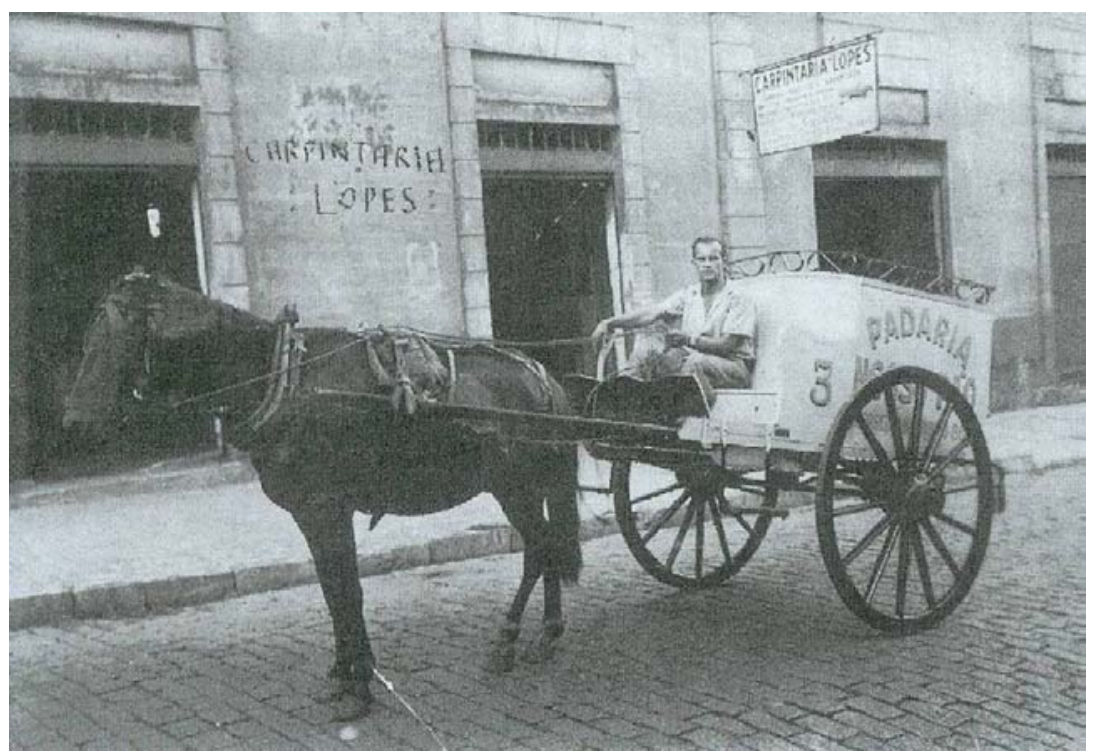


PORTUGUESES E EXPERIÊNCIAS POLÍTICAS:...

Nesta atividade, os ganhos eram parcos, alguns trabalhavam por anos sem receber nada a não ser a hospedagem e um prato de comida, mesmo para os mais gabaritados, os pagamentos eram instáveis, eles poderiam ampliar ganhos com a venda do pão em domicílio.

A maior parte dos trabalhadores das padarias (homens solteiros) morava no local de trabalho, uma espécie de alojamento fornecido pelo proprietário, que também fornecia as refeições, o que facilitava aos recém chegados, pois os livrava das despesas com acomodações, transporte e alimentação. Contudo, os cômodos eram precários, sujos, mal arejados e a comida não podia ser considerada boa. Cabe observar que essas ações eram estratégias patronais de controle sobre o cotidiano e o horário de trabalho dos trabalhadores, garantia de assiduidade e pontualidade e possibilidade de extensão da jornada, buscando disciplina, criando dependência e outros vínculos.

O dono da padaria - o português - escolhia o padeiro e seus ajudantes, fornecia o local e a matéria prima e cobrava produção. Buscava o controle, através do número de pães que cada saca de trigo produzia, mas esse número dependia da qualidade da farinha e das habilidades do padeiro. Também se controlava a produção através da vigilância do processo de trabalho, chegando-se a trancar a sala da padaria restringindo a saída dos padeiros.

\section{Aprendia-se a trabalhar - trabalhando.}

Aprendia-se a ser padeiro na própria padaria. Os jovens principiantes observavam o processo de preparação do pão atuando como auxiliares, alguns entravam com 8, 10 anos, eram filhos e parentes ou amigos do próprio padeiro ou do dono da padaria. $O$ processo de aprendizagem era lento, incluindo submeter-se a várias atividades: peneirar o carvão, rachar lenha, colocar lenha no forno, limpeza do forno, carregar os sacos de farinha, enrolar os panos, ajudar a fazer a massa, limpar e varrer a padaria, atender no balcão, fazer entregas. Eram atividades 
que demandavam força: aguentar peso, carregar o cesto com 60 pães, conhecer as redondezas e a freguesia, enfrentar a longa jornada, entre outras.

Dependendo das habilidades e dedicação, poderia passar para amassador, padeiro e forneiro.

Quando cheguei fui trabalhar com meu irmão, era caixeiro, era tudo... ajudava a amassar levantava às 2 de manhã, ajudava no balcão e a distribuir o pão. Morava na padaria... ${ }^{19}$

Reforçando esse depoimento, os anúncios de jornais deixavam clara a preferência:

Caixeiro precisa-se de um pequeno de 14 a 16 anos, português, com prática em padaria, que seja trabalhador, obediente e honesto. Exige-se referências. Tratar à .... ${ }^{20}$

Os imigrantes ao chegar contavam com o apoio dos parentes ou conterrâneos já radicados, sendo prática mandar chamar parentes, conhecidos, jovens da aldeia para ajudar nos negócios, eram considerados de confiança. Mas cabe lembrar que em alguns casos a ajuda se transforma em exploração do trabalho desses conterrâneos mais jovens e pobres, desprotegidos em ambiente desconhecido, assim, exploração e paternalismo coexistiam nas casas comerciais, oficinas e nos lares ${ }^{21}$.

A necessidade das crianças desde cedo se engajarem no trabalho, fosse nas fábricas, oficinas ou nas ruas, além de ser fruto das necessidades dos imigrantes pobres, também era vista como possibilidade da obtenção de um ofício que lhes garantisse um futuro mais promissor ${ }^{22}$.

Os aprendizes, padeirinhos e caixeirinhos trabalhavam em troca de casa e comida, numa rotina que incluía limpeza da padaria, atendimento dos fregueses nos balcões, lidar com estoques, carregar e entregar mercadorias. Buscando formar trabalhadores produtivos, obedientes e dóceis, patrões e mestres impunham práticas austeras, medidas destinadas a inculcar nas crianças hábitos de trabalho, hierarquias, disciplina 
que incluíam castigos físicos, punições. Assim, as condições de trabalho e de vida durante o aprendizado compreendiam a prática do castigo físico, outras práticas vexatórias e punições aviltantes e violentas, dormir debaixo dos balcões ou no ladrilho da padaria, tornando as fugas frequentes.

Nos processos, crimes, e nos jornais liam-se notícias como a do menor Alfredo Júlio Machado, português de 11 anos de idade que foi se queixar ao delegado de polícia por ter sido espancado pelo seu "amo" José Rodrigues Tavares, também português ${ }^{23}$.

Em geral, esses jovens trabalhadores permaneciam nos domicílios e negócios desses parentes, arcando com os afazeres muitas vezes sem nada receber, outras vezes parcamente remunerados ou submetendo-se a pagamentos incertos. Solidariedade e paternalismo não eram apenas formas de exploração, mas também estratégias de sobrevivência e de lidar com os recursos possíveis (THOMPSON, 1984).

\section{Ganhar o pão com o suor do próprio rosto}

Em 1877, depois de organizar um "levante" que paralisou as padarias do porto de Santos (1876), João de Mattos rumou para São Paulo onde preparou outro "levante" bem sucedido, reunindo os trabalhadores de 12 padarias da cidade.

Fugindo da polícia paulista, em 1878, ele chegou ao Rio de Janeiro para organizar ações similares e na Corte, criou o Bloco de Combate dos Empregados em Padarias, que tinha como lema "Pelo pão e pela liberdade" (MATTOS, 2007). Outras associações, cooperativas e ligas foram constituídas com a sua participação, bem como, a edição de periódico da categoria como O Panificador (desde 1898/RJ) ou O Trabalhador Padeiro (SP).

Desde os primórdios da expansão das padarias na cidade de São Paulo, as questões em torno das condições de trabalho e da entrega dos pães geravam embates entre patrões e trabalhadores, produzindo ações de resistência e luta constantes durante o século XX. 
Nos anos 20, a União dos Padeiros que coordenava a categoria, encabeçou a greve (1924), que tinha como motivo a reivindicação da troca de alojamento e comida por melhores salários.

Experiências de luta da categoria culminaram na institucionalização de um sindicato em 16 de novembro de 1930 (Sindicato dos Manipuladores de Pão, Confeiteiros e Similares de São Paulo), que nasceu sob o signo da organização e combatividade.

A questão do descanso semanal dos padeiros em São Paulo, iniciada em 1922, arrastou-se até 1931, quando o benefício foi estabelecido por lei ${ }^{24}$. A Associação dos Proprietários de Padarias de São Paulo insatisfeita tentou impedir a execução da medida, entrando com pedido de inconstitucionalidade, mas a sua legalidade foi reconhecida. Contudo, na prática, a situação era outra, a resistência dos patrões em implementar a medida era constante e anos depois, a questão ainda se fazia presente da pauta de demandas dos grevistas.

Em 1931, o Sindicato dos Manipuladores de Pão, afiliado à Federação Operária de São Paulo (FOSP), mobilizou-se em prol do descanso dominical. Militantes anarquistas como Francisco Cianci, Herminio Marcos e Natalino Rodrigues foram registrados como indivíduos sempre presentes em assembléias e conferências da categoria.

Atingindo diretamente o abastecimento da cidade, em 1932, eclodiu uma nova greve da categoria que durou um mês. Nesta ocasião, as reivindicações se concentravam em aumento salarial, nos horários das atividades, no trabalho noturno e nas folgas semanais. Apesar dos inconvenientes da falta de pão, o Sindicato procurou o apoio da população, valendo-se da imprensa, divulgou no Diário de São Paulo, que eles defendiam a fiscalização sanitária e higiene nos locais de trabalho, além das demandas da classe ${ }^{25}$.

Durante a paralisação, a liderança sofreu forte repressão policial, principalmente depois dos embates entre os mais engajados e os colegas que não aderiram à paralisação, sendo enviados policiais para garantir o funcionamento de padarias. 
Vários padeiros foram presos, entre eles, o líder anarquista Natalino Rodrigues ${ }^{26}$.

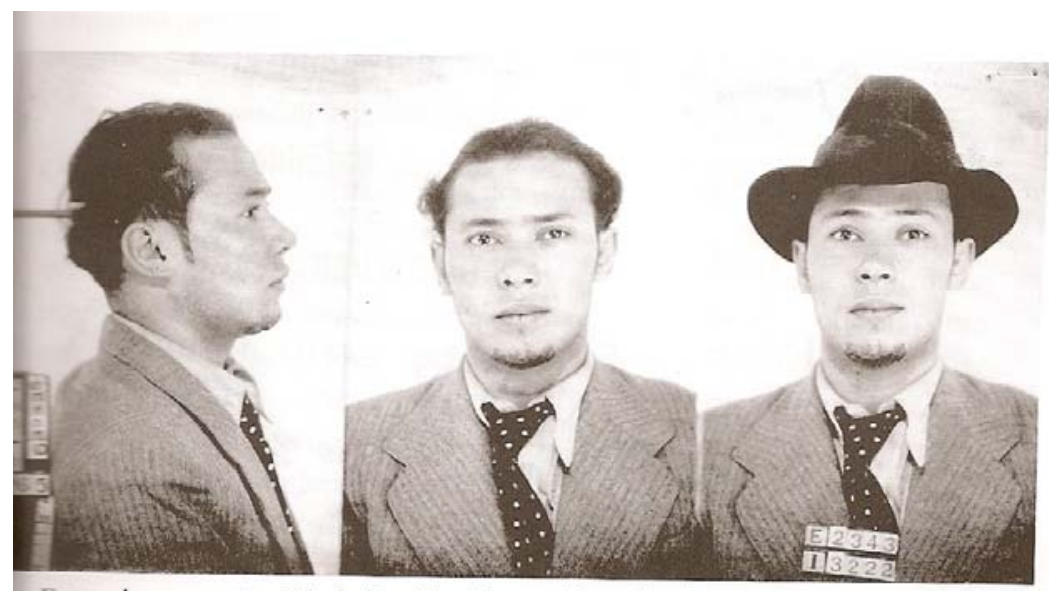

Fotos do anarquista Nathalino Rodrigues, identificado em 1932. Laboratório Técnico de Fotografia do Gabinete de Investigação. Pront 1286 Nathalino Rodrigues. DEOPS/SP. DAESP.

Já as paralisações de 1934/35 se constituíam frente às recusas da categoria ao registro e identificação via carteira de trabalho, associada às novas medidas decretadas pelo Ministério do Trabalho. O Sindicato colocava-se contrário ao registro, visto como um novo elemento de controle dos trabalhadores. Acusava o Departamento Estadual do Trabalho de forçar a identificação, fazendo com que os patrões exigissem dos empregados fotografias e fichas, com o fim de pôr em prática encargos e identificar dos trabalhadores mais engajados (PARRA, 2003). Essa resistência pode também ser explicada pela elevada presença de estrangeiros na categoria, sugerindo uma ameaça, já que entre os portugueses, a quantidade de imigrantes irregulares era sempre alta (SILVA, 2005). 
As lideranças do Sindicato dos Manipuladores de Pão, Confeiteiros (com sede no prédio da Rua Quintino Bocaiúva, $\mathrm{n}$. 80), bem como suas reuniões, encontravam-se sob permanente vigilância policial. O que levou a novas prisões de vários líderes envolvidos, como Natalino Rodrigues, considerado "um de seus principais dirigentes e organizadores da greve, agitador e provocador de distúrbios". ${ }^{27}$ Também Eleutério do Nascimento...

(português-padeiro) era sócio do Sindicato dos Manipuladores de Pão e Anexos Confeiteiros. Foi preso em maio de 1934, acusado de ter alvejado Antonio Conceição, que era participante de uma greve. Em setembro do mesmo ano, Eleutério foi novamente preso, acusado de agitador. Em 1935, foi preso por duas vezes, sendo a ultima por suspeita de roubo. ${ }^{28}$

As ações provocaram o fechamento, pela polícia, do Sindicato dos Manipuladores de Pão, suspendendo temporariamente a circulação do o jornal $O$ Trabalhador Padeiro ${ }^{29}$.

Uma nova greve eclodiu em 1937. As reivindicações dos padeiros incluíam várias demandas: cumprimento da lei das oito horas de trabalho, salário mínimo e férias, pagamento em dinheiro dos que recebiam em comida e alojamento (equivalente a aumento de salário de 120 réis, correspondente a pensão e dormitório), direito ao café e a um quilo de pão para cada operário.

que a greve foi iniciada por alguns manipuladores de pão que não podiam suportar a alimentação que lhes era fornecida pelos patrões; que ordenado, quase geral, é de cento e oitenta mil reis mensais, com direito a comer e a dormir na padarias, que os descontentes pleitearam uma diferença para mais de cento e vinte mil reis mensais para a pensão... ${ }^{30}$

Frente à forte resistência dos proprietários, a greve teve início em 21 de agosto atingindo várias padarias ${ }^{31}$. O movimento ganhou novas adesões e, no dia seguinte, a maior parte das padarias não funcionou. 
PORTUGUESES E EXPERIÊNCIAS POLÍTICAS:...

Só abriram as portas os poucos que fizeram acordo, em separado, com os seus masseiros. Mas a produção dos raros estabelecimentos em atividade era insuficiente para abastecer... $^{32}$

A posição patronal manteve-se, as demandas dos padeiros eram consideradas descabidas e eles identificados como agitadores. Em resposta, os patrões iniciaram um locaute fechando as padarias e revidando com a demissão de mais de 400 empregados de 41 padarias ${ }^{33}$. Os sindicalistas replicaram denunciando que donos de padaria estavam criando pretextos, para elevar o preço do pão.

Apesar dos aconselhamentos iniciais da Associação dos Proprietários sobre a conveniência de negociar com as lideranças dos trabalhadores, foram poucos os estabelecimentos que aceitaram as reivindicações, fechando acordo com seus empregados. Na maioria das padarias, não foi possível um entendimento. Com o recrudescimento e o acirramento das ações, abandonaram-se as negociações, os patrões endureceram a posição e os poderes públicos aumentaram a vigilância policial, levando à prisão de vários envolvidos.

Outras duas categorias do setor: carvoeiros e entregadores em domicílio, envolveram-se na questão. Ficando os carvoeiros alinhados com os donos de padaria, enquanto os entregadores de pão declararam greve em apoio ao movimento dos padeiros.

$\mathrm{Na}$ madrugada de quarta-feira, em vários bairros da cidade, ocorreram brigas e detenções de grevistas, em geral motivadas pelo confronto de piqueteiros com entregadores que insistiam em sair com suas carroças para o trabalho. Como descrevia o Dr. Miranda Amaral, Delegado de plantão:

Ilmo Sr. Dr. Superintendente da ordem política e social da capital Comunico-vos que durante o meu plantão das 12 horas de ontem às 12 horas de hoje, nesta superintendência verificamos.

Às 4 hrs recebi uma comunicação do guarda de serviço na $R$. Barão de Campinas esquina com a Alameda Glete, avisando que um grupo de entregadores de pão se encontrava de fronte da 
Padaria e confeitaria Inglesa, situada na mesma rua, a espera da saída das carrocinhas de pão, afim de atacarem os entregadores. Transportei-me ao local e fiz remover os agressores para esta superintendência. Apreendi um revolver em poder de Mauricio Gambá e uma pistola em poder de Manoel Gonçalves de Oliveira, empregados da padaria em questão que utilizavam as referidas armas em defesa própria.

Ás 5 hrs no Alto da Lapa os grevista Manoel Carvalho, Manoel de Sá Pinto, Jalmires Pinho Ribeiro e Antonio Sá Pinto tentaram agredir os entregadores de pão Joaquim Fernandes e Manoel Antonio Quintas, depois de se apoderar de todo o pão que traziam, os mesmos declararam que iam entrega-lo a Gazeta para distribuição aos pobres. Fiz recolhe-los ao xadrez desta superintendência.

Ás 6 hrs, na rua do Glicério, foram detidos e recolhidos ao xadrez os indivíduos Alpheu de Souza e Manoel de Almeida Cardoso por terem sido encontrados distribuindo boletins cujos exemplares passo às suas mãos. Junto a comunicação do sr. comandante da guarnição desta superintendência.

Miranda Amaral

Delegado de plantão 26/8/1937. ${ }^{34}$

Pode-se observar que os envolvidos foram presos, como o entregador lusitano José Joaquim da Silva, quando tentava convencer seus colegas a não trabalhar ${ }^{35}$. Outra agressão registrada, ao fura-greve, também português, Manoel Antunes Quintas, atacado por outros entregadores, que tomaram seus pães e os distribuíram aos pobres ${ }^{36}$. $\mathrm{O}$ acirramento da situação levou à ação policial, que buscou colocar um soldado armado para cada carrocinha de entrega em atividade.

O Sindicato dos Proprietários divulgou uma proposta: aumento para 870 réis (como teto da categoria), alguns estabelecimentos acataram a sugestão e fizeram acordo com seus empregados, voltando às atividades normais; mas a maioria dos patrões recusou a indicação e por temor a 
represálias, suspenderam o serviço de distribuição e mantiveram fechadas as padarias.

...mas os patrões não se conformaram e promoveram a greve pagando os vencimentos dos manipuladores e proibindo-os de trabalhar; que, com a falta de pão, os vendedores viram-se prejudicados e procuraram defender seus interesses; que na realidade os maiores prejudicados foram os vendedores que nada tinham com a questão dos manipuladores; que o declarante e seus companheiros que foram detidos ontem na rua Conselheiro Nébias, não praticaram, nem tinham intenção de praticarem quaisquer violências contra os referidos vendedores. ${ }^{37}$

Frente a tal situação, durante a segunda semana da greve, a diretoria da Liga dos Entregadores de Pão retirou seu apoio aos padeiros, buscando uma posição de neutralidade e até se apresentou disposta a intermediar o conflito. Mas havia entregadores que se mantinham favoráveis ao movimento, gerando novos enfrentamentos.

Manoel Soares declarou que ele e seus companheiros, Antonio Gonçalves Grillo, José Joaquim da Silva, Antonio dos Santos, José Soares de Azevedo, Rogério Augusto Venâncio e Avelino Costa foram detidos na madrugada de ontem, pelas quatro horas. $\mathrm{Na}$ Alameda Glete e, sendo que alguns foram detidos na Rua Conselheiro Nébias; que o declarante não conhece os quatro queixosos acerca do fato, nada podendo dizer sobre os mesmos; que o declarante ouviu que os queixosos ao serem interpelados pelos companheiros do declarante quiseram fazer uso de armas de fogo, porém o declarante não viu esta arma; que os companheiros, primeiros referidos queriam convencer os quatro queixosos de que não deviam voltar ao trabalho afim de não prejudicar a greve dos vendedores e manipuladores de pão; porém a policia interveio no momento oportuno...que além de prejuízo que causariam a greve, prejudicariam também os colegas tomando-lhes a freguesia... ${ }^{38}$

As padarias buscaram contratar novos entregadores, que, diferentemente dos padeiros, tinham uma função que poderia 
ser exercida por quem soubesse conduzir a carrocinha. A distribuição do pão tendeu a ser normalizada, os grevistas foram ficando isolados, gradativamente, o movimento foi se esvaziando e os padeiros buscaram se acertar com os patrões.

Esta greve dos padeiros durou 12 dias. Nos meses subsequentes instaurou-se o Estado Novo, as ações de repressão do DEOPS se efetivam na capital paulista, neste processo, novamente os padeiros e entregadores de origem lusitana estiveram envolvidos.

Em 1939, as autoridades policiais alegavam que o Sindicato dos Manipuladores de Pão era ilegal, por não ter sido ainda registrado pelo Ministério do Trabalho. Para que o sindicato fosse legalizado, deveria comprovar boa conduta de seus membros. Levando o Sindicato a retirar da porta de sua sede, em 1940, a placa de "Sindicato" e a substituí-la pela de "Associação"

\section{Nos papéis da repressão}

Não se habita impunemente em outro país, não se vive no seio de uma outra sociedade, de uma outra economia, em "um outro mundo", em suma, sem que algo permaneça dessa presença, sem que se sofra mais ou menos intensa e profundamente, conforme as modalidades de contato, os domínios, as experiências e as sensibilidades individuais, por vezes, mesmo não se dando conta delas e, outras vezes, estando plenamente consciente dos efeitos (SAYAD, 2000).

A trajetória histórica de homens e mulheres imigrantes, particularmente portugueses, envolveu uma heterogeneidade de atividades com destaque para as comerciais. Alguns obtiveram rendas relativas, com probabilidade de ascensão social, outros sobreviveram através de estratégia e improvisações cotidianas.

No setor comercial, os imigrantes portugueses identificaram as possibilidades da realização do sonho da imigração. Da mesma forma que em outras cidades, pode-se destacar que: 
Falar da imigração portuguesa significa mergulhar em um espaço privilegiado: o do comércio, destino mistificado para todos aqueles que acalentavam sonhos de promoção social no alémmar. Nesse espaço significava, ainda, privilegiar dois atores principais do drama cotidiano: negociante e o caixeiro, figuras emblemáticas que se fizeram presentes no espaço urbano ao longo de todo o processo de urbanização. A medida que expandiu a malha urbana, o comércio português a varejo acompanhou esse crescimento tornando o português da esquina referência obrigatória... (MENEZES, 2000)

O balcão da padaria era também um palco das tensões do cotidiano envolvendo cobranças, atrasos e recusa no pagamento das contas consideradas abusivas, hostilidades, brigas, provocações, insultos, xingamentos e manifestações de antilusitanismo.

$\mathrm{Na}$ trama destas relações se destacam os vínculos de nacionalidade e memórias em comum, a ajuda aos conterrâneos na hora da chegada, hospedagem e empréstimos, também o estabelecimento de relações de confiança (gerencia e até sociedade nos negócios), favores e dependências. Mas, principalmente, de tensões, ao final era o dono da padaria - o português - que escolhia o padeiro e seus ajudantes (muitos também portugueses), sempre buscando manter o controle e a sujeição dos trabalhadores.

Os prontuários do DEOPS possibilitam observar os embates entre trabalhadores e proprietários, também os conflitos intra-étnicos, alguns que culminaram em greves e enfrentamentos, com a presença da polícia e a identificação e prisão dos mais atuantes.

\section{REFERÊNCIAS BIBLIOGRÁFICAS}

CERTEAU, Michel, A invenção do Cotidiano II, Petrópolis, Vozes, 1996. DEMARTINI, Zeila Brito Fabri. Imigração, Família e Educação, V Congresso Luso-brasileiro de História da Educação, Évora, 2003. 
ELIAS, Norbert. O processo civilizador. RJ, Jorge Zahar, 1994. FONTES, Edilza. O Pão nosso de cada dia, Belém, Paka-tatu, 2002. LOBO, Eulália Maria L. Imigração portuguesa no Brasil. SP, Hucitec, 2001. PERISSINI, Nilmara Cristina. Da União á Fundação: a história da panificação em São Paulo, São Paulo, Mundial, 2005.

MATOS, Maria Izilda Santos de. Cotidiano e Cultura. SP, EDUSC, 2002.

MATTOS, Marcelo Badaró. Experiências comuns: escravizados e livres no processo de formação da classe trabalhadora no Brasil, in Anais do XXIV Simpósio Nacional de História, 2007, São Leopoldo.

MENDES, José Sacchetta Ramos. "Fornada de conflitos: portugueses na greve dos padeiros de 1937", in: Metrópole das Utopias, no prelo.

MENEZES, Lená Medeiros "Jovens portugueses: Histórias de sucesso, histórias de trabalho, histórias de fracasso". In GOMES, Ângela de C. (org.) Histórias de imigrantes e de imigração no Rio de Janeiro. RJ, Sette Letras, 2000.

PARRA, Lucia Silva. Combates pela liberdade: o movimento anarquista sob a vigilância do DEOSP (1924-45). SP, Arquivo Estado/Imprensa Oficial do Estado, 2003.

ROLNIK, Raquel. "História Urbana: História na Cidade". In: FERNANDES, Ana; GOMES, Marco Aurélio, Cidade e História: modernização das cidades brasileiras nos séculos XIX e XX. Salvador: Faculdade de Arquitetura, 1992.

SAYAD, A O retorno: elemento constitutivo da condição do imigrante, Travessia Revista do Migrante, SP, v. 13, jan/2000.

SILVA, Rodrigo Rosa da. Imprimindo a Resistência: A Imprensa Anarquista e a Repressão Política em São Paulo (1930 -1945). Mestrado, UNICAMP, 2005.

SILVA, Siwla Helena. Restaurant à moda de Paris: mudanças culturais e o surgimento do restaurante na cidade de São Paulo (1855-70), Mestrado, PUC/SP, 2007.

THOMPSON, E. P. Tradicion Revuelta y conciencia de clase. Estudios sobre la crisis de la sociedad pre-industrial, Barcelona, Editorial Crítica, 1984. 
MATOS, Maria Izilda Santos de. The Portuguese and political experiences: The struggle and the bread. Sao Paulo 1870-1945. História, v.28, n.1, p.415-444, 2009.

\begin{abstract}
This article is intended to be a contribution to the study of the everyday experiences of immigrants in the city of Sao Paulo during the period between 1870 and 1945. The analysis will seek to recapture the web of relationships in their everyday life and experience with respect to business and labor, relating aspects of their activities in the production and marketing of bread, and observing the interchange of communication and tensions that were prevalent between the owners and workers of the bakeries of which most of them were of Portuguese origin. Focusing mainly on documents from DEOPS (State Department of Political and Social Order), particularly the charts, the article retrieves information concerning confrontations, forms of resistance, struggles and strikes that plagued the bakery sector.
\end{abstract}

Keywords: Portuguese immigrants; Bakers; Sao Paulo; Everyday life.

\title{
NOTAS
}

${ }^{1}$ Ministério da Agricultura, Indústria e Comércio. Recenseamento do Brasil, 1920, Sinopse do Recenseamento. Rio de Janeiro, Tip. de Estatística, 1926.

${ }^{2}$ Deve-se destacar a noção de territorialidade, identificando o espaço enquanto experiência individual e coletiva, onde a rua, a praça, a praia, o bairro, os percursos estão plenos de lembranças, experiências e memórias. Espaços que, além de sua existência material, são também codificados por todo um conjunto de representações, numa dinâmica de múltiplos processos de territorialização, desterritorialização e reterritorialização (ROLNIK, 1992).

${ }^{3}$ Cabe destacar que não houve um único padrão de deslocamento dos grupos familiares, muitos imigrantes eram chefes de família, vieram bem antes de seus familiares que ficaram aguardando; outros vieram ainda quando crianças ou jovens, sem a família nuclear; em outros casos, a família nuclear veio junta, e, mas em alguns deles não 
permaneceram unidas no novo contexto ou nunca se encontraram e/ou não voltaram a se constituir (DEMARTINI, 2003).

${ }^{4}$ Entre 1910 e 1914, ocorreu um aumento considerável da imigração lusitana para São Paulo. Os imigrantes portugueses se destacam nas atividades comerciais; no atacado, nos negócios do café, trigo, arroz, milho, batatas e cebolas, na importação e exportação de gêneros alimentícios, em especial, vinhos, azeites e conservas, também no setor têxtil, fios, tecidos e artefatos de tecidos e vestuário. Estes comerciantes eram a maioria entre os estrangeiros, em número superior ao dos sírio-libaneses e italianos. Censo de 1950, São Paulo, Nacionalidade dos proprietários e sócios de firmas individuais e sociedade de pessoas do comércio varejista segundo gênero de comércio. (LOBO, 2001).

${ }^{5}$ As adegas, além de venderem bebidas e petiscos, serviam refeições avulsas a preços módicos.

6 As mercearias vendiam produtos variados: frutas nacionais $\mathrm{e}$ importadas, laticínios, manteiga, frios, azeite, azeitonas.

${ }^{7}$ Nos domicílios, mulheres exímias na cozinha, produziam guloseimas (balas e pastéis, biscoitos, tortas, petiscos) que, independentemente das proibições, eram comercializadas em bandejas e cestas, nos Jardins, praças e nas saídas das igrejas, particularmente nos domingos e feriados, nos dias santos e de procissão.

${ }^{8}$ Referências simbólicas e culturais constituíram significados sobre o pão, sua presença simboliza fartura, abundância, sua falta identifica carência, fome e miséria. O cristianismo identifica o pão ao corpo divino, além de clamar pelas bênçãos do "pão nosso de cada dia". Lutas e movimentos sociais foram constituídos clamando pelo pão, como denúncia da situação de miséria a que estavam submetidos certos setores sociais. No Brasil, como na Europa, o preparo e consumo do pão acompanhavam rituais e cerimônias, como fazer cruzes nas massas, rezar salmos para fazê-los crescer e ficarem macios e bonitos. "O pão suscita o respeito mais arcaico, é quase sagrado. Jogá-lo ao chão, pisá-lo é visto como sacrilégio... O pão é memorial." (CERTEAU, 1996)

${ }^{9}$ As queixas dos consumidores à Câmara Municipal sobre a qualidade do pão eram frequentes.

10 Cozinhar é transmissão de um saber geracional, de tradições, vinculada à memória familiar e da comunidade de origem, envolve gestos, ritos e códigos herdados e repetidos. $\mathrm{Na}$ preparação do alimento, precisava-se orçar a disponibilidade do recurso, observar na 
compra e a qualidade dos ingredientes, calcular o tempo de preparo e as porções para não ter desperdício ou falta (CERTEAU, 1996).

${ }^{11}$ Só em 1920 apareceram as primeiras padarias mecanizadas. Em São Paulo, havia um total de 8.860 padarias em 1950 e mais de 13 mil nos anos 60. Na década de 70, passou para 70 mil, com um consumo de mais de um milhão de toneladas de pão por ano.

${ }^{12}$ Este tipo de pão é feito de uma variedade de trigo e por uma forma especial de preparo, difundida nos arrabaldes de Lisboa.

${ }^{13}$ Prontuário DEOPS-SP no. 1899 - Eleutério Nascimento.

${ }^{14}$ A Plebe, no. 72, 29/09/1934.

${ }^{15}$ Através da lei n. 2.503 (sancionada em dezembro de 1922), também se passou a exigir a regulamentação dos entregadores de pão perante os órgãos de fiscalização pública com exame para obtenção da carteira de cocheiro (artigo 71, ato n. 1426 de abril/1920).

${ }_{16}$ Nos anos 30, também foi criado o Sindicato dos Industriais de Panificação e Confeitaria de São Paulo, reconhecido pelo Ministério do Trabalho, dessa forma o setor patronal adquiriu dupla representação.

${ }_{17}$ As masseiras elétricas começaram a ser utilizadas em meados da década de 1920, mas sua difusão foi lenta e parcial, sua incorporação mais generalizada ocorreu a partir dos anos 40 .

${ }^{18}$ A compra ou repasse de uma freguesia era uma responsabilidade e deveria ser precedida de uma apresentação, pois o freguês mantinha fidelidade ao seu padeiro, bem como havia um respeito às zonas de ação.

${ }_{19}^{19}$ Depoimento fornecido a autora 12/4/2004, por Antonio Pedrão, português de 82 anos.

${ }^{20}$ Diário de São Paulo, 1926.

${ }^{21}$ Os estudos históricos sobre a infância permitem questionar a noção genérica de criança, recuperando a historicidade da categoria, a heterogeneidade de experiências e as variações das noções. Não se tinha a noção de criança como um indivíduo dependente da família e da sociedade, carente de proteção, o que levou ao ingresso precoce no mundo do trabalho. $O$ trabalho das crianças era utilizado desde cedo na Europa, tanto no campo, como nos lares e nas oficinas, era necessário para manutenção da família, fator de formação e ocupação profissional, condição indispensável para o desenvolvimento físico e moral. A criança era compreendida como uma criatura amoldável, devendo ser submetida a um conjunto de normas de comportamento e hierarquias, identificadas como uma forma de educação, estas práticas contavam com o respaldo de pais, irmãos e parentes. 
${ }^{22}$ Entre as pequenas profissões que predominavam no cenário urbano de São Paulo destacava-se o artesanato autônomo, em pequenas oficinas caseiras, localizadas em algum cômodo ou fundo de quintal, muitos portugueses trabalhavam como carpinteiros, ferreiros, ourives, sapateiros, calígrafos, alfaiates, seleiros, gravateiros. Essas atividades envolviam grupo familiar: mulher, filhos, algum conterrâneo ou agregado, o fato de crianças serem desde pequenas introduzidas no aprendizado e utilizadas como ajudantes de seus pais fez com que muitas destas profissões adquirissem tradição hereditária, passando de geração a geração, era o caso dos habilidosos marceneiros, serralheiros, alfaiates, costureiras e bordadeiras de origem lusitana. Conquistando clientela, muitos montavam negócios por conta própria e conseguiam expandir-se economicamente, chegando à posição de pequenos empreendedores (MATOS, 2002).

${ }^{23}$ Diário de São Paulo. 6/12/1886.

${ }^{24}$ Lei n.2.563/31 do município de São Paulo; lei federal n. ${ }^{\circ}$ 19.770/31, sobre organização sindical dos masseiros e forneiros de padaria.

${ }^{25}$ Prontuário: 868 - Associação dos Manipuladores de Pão e Confeiteiros e Similares de São Paulo.

${ }^{26}$ Prontuário DEOPS-SP no. 1286 - Nathalino Rodrigues.

${ }^{27}$ Prontuário DEOPS-SP no. 1286 - Nathalino Rodrigues.

${ }^{28}$ Prontuário DEOPS-SP no. 1899 - Eleutério do Nascimento.

${ }^{29}$ José Rocca Orozco foi preso em 19 de fevereiro de 1937, acusado de anarquismo. Foi redator do jornal $O$ Trabalhador Padeiro. Recebia jornais de sindicatos e associações de classe da Espanha. Prontuário DEOPS-SP no: 2393. Prontuário DEOPS-SP no: 868 - Associação dos Manipuladores de Pão e Confeiteiros e Similares de São Paulo

${ }^{30}$ Prontuário DEOPS-SP no. 4265 - José Soares de Azevedo. Percebe-se se que o DEOPS estava atento às atividades do Sindicato dos Manipuladores, quando foi dissolvida uma assembléia, por falta de autorização necessária para a sua realização. A partir de então, todas as pautas de reuniões eram entregues ao DEOPS com antecedência. Prontuário: 868 Associação dos Manipuladores de Pão e Confeiteiros e Similares de São Paulo.

31 Prontuário DEOPS/SP no. 4.162- Associação dos Proprietários de Padaria de São Paulo.

${ }^{32}$ Mendes, José Sacchetta Ramos. "Fornada de conflitos: portugueses na greve dos padeiros de 1937", in: Metrópole das Utopias, no prelo.

33 "Sobre a Greve dos Padeiros". In: O Estado de S. Paulo. São Paulo, 24.08.1937, p. 10. citado por Mendes, José Sacchetta Ramos. Op.cit. 
${ }^{34}$ Prontuário DEOPS-SP no. 448326 /8/ 1937

${ }^{35}$ Prontuário DEOPS-SP no. 4169 - José Joaquim da Silva.

${ }^{36}$ Relatório de Investigação. São Paulo, 26.08.1937. Prontuário DEOPSSP n. 4297 - Manoel Antunes Quintas.

${ }^{37}$ Prontuário DEOPS-SP no. 4265 - José Soares de Azevedo.

38 Os prontuários dos portugueses no DEOPS-SP, referente a este momento de 1937, no. 4212 - Manoel Soares; 4274 - Rogério Augusto Venâncio; 4188 - Manoel de Sá Pinto; 4273 - Manoel de Almeida Cardoso; 4265 - José Soares de Azevedo; 4304 - Manoel de Carvalho.

39 Prontuário: 868 - Associação dos Manipuladores de Pão e Confeiteiros e Similares de São Paulo (MENDES, no prelo).

Artigo recebido em 02/2009. Aprovado em 05/2009 